\title{
BUILDING ON SAND: Nation, Borders, Myth and History
}

\section{Transforming Cultures eJ ournal, \\ Vol. 1 No. 1, March 2006 http:// epress.lib.uts.edu.au/journals/TfC}

\section{Introduction}

Heather Goodall

Trans/forming Cultures

February 2006

Symposium held by Trans/forming Cultures and RIIA at UTS August 2004.

Building on Sand brought together scholars with high profile roles as public intellectuals whose work is engaged in three very different geographic areas: Australia, Israel/Palestine and India/Pakistan. Each of these, as the conjoined names of two suggest, are sites of conflict over the nature of the civil and social authority which holds power and the peoples who claim to belong there. History has been a central theme in the rhetoric of these political conflicts, in which a unitary and authoritative history for a 'nation' and a 'state' has been built on the shifting sands of always-emerging historical evidence and its interpretations. In each of these three regions, a history which celebrated national formation and unity was challenged by 'new' historians in the 1970s [or 1980s or 1990s]. They used a similar set of methodologies like oral history, popular culture and the built environment: the toolkit of researching "history from below" for a generation of social and cultural historians. Such new histories have now been challenged themselves by a reassertion of the validity of a celebratory 'national' history based on unproblematic, 'factual' evidence. These recent conflicts between the 'new' historians and the (even newer) re-asserters of a 'national' history have been bruising encounters, with high stakes in terms of individual reputations, public emotions and the real, personal safety in some cases of the participants and, more importantly, of vulnerable oppositional communities.

The symposium did not seek to reprise the course of any of these conflicts, although some speakers gave an overview. Instead, speakers were asked to talk on what their questions were now in response to these conflicts. What did these scholars, each 
reflecting on their engagement in bitter public debate, see as the most pressing questions for them to pursue?

The papers published here are by Tony Birch, Ann Curthoys and Ghassan Hage about Australia; and by Ilan Pappe on Palestine and Israel. All the symposium speakers were asked to offer works in progress at the conference. Some papers are not published here, like the papers by Devleena Ghosh on India and Pakistan, by Lyndall Ryan on Tasmania, by Ihab Shalbak on Palestine and by Ephraim Nimni on the possibilities for a non-territorial nationalism. Each continues to be developed into a larger work. Other papers, like that of Ann Curthoys, have already contributed to broader published material like the important volume Is History Fiction (Curthoys, A. \& Docker, J. 2005). While some are refereed, others, like the paper by Ghassan Hage, is an unrefereed reflective 'think piece' which sketches in the outlines of current debates or future directions. Those which are published here reflect, however, the themes and questions with which all the symposium participants grappled.

The national conflicts in the three regions have of course moved on since 2004. In Palestine and Israel, the armed Israeli occupation of the West Bank continues while the colonizing settlements expand, but the occupation of Gaza is claimed by the Israelis to be over. Israeli Prime Minister Arial Sharon lies in a coma and his successor is untested. Democratic elections for the Palestinian authority have brought Hamas to power and high tensions remain with Fatah supporters and other secular Palestinians. In India, a terrifying earthquake has shattered Kashmir as well as eastern Pakistan. There have been changes of government in India and there has been international pressure on Pakistan over the 'War on Terror'. The high tensions between Pakistan and India are wavering and fluid. In Australia, the conservative government under Howard has established a grudging truce with Indigenous Australia and the question of what 'sovereignty' ever meant is being submerged under a tide of 'mainstreaming'. Yet the questions raised in each of these papers remain not only relevant but urgent.

There were four themes which recurred in all the Building on Sand symposium papers but were approached in different ways. One was the production of 'history' in the intensely politicized conditions of the nation state, understood to be a recent political form generated by the historically specific conditions of the $19^{\text {th }}$ and $20^{\text {th }}$ centuries. Was 
it necessary for a 'nation' to seek a simple, unitary story of origins or could it seek a future in embracing conflicting narratives of possession, invasion and dispossession? Was a national history inevitably going to involve the cultural and often physical erasure of the places and stories of defeated indigenous peoples? Ihab Shalbak in relation to Palestine and Tony Birch in relation to Australia both argued that the nation states with which they took issue, Israel and Australia respectively, had done just that. Each had undertaken the physical removal, by violence or dispossession, and the obliteration in the national narrative, of the colonized peoples of the land the settler colonizers occupied. In his own beautiful prose and through the poetry of Minoru Hokari, Birch reflected on the intense politicization of the 'phoney war' over history in Australia, seeing it as a continuation of a culture of silencing. He challenges the right of non-Indigenous historians to speak on behalf of Indigenous histories and in doing so, Birch charts the futility of such 'phoney' collaborations. Shalbak detailed the physical and imaginative obliteration of the Palestinian village of Ayn Hawd and its substitution in real space in northern Palestine, in virtual space on the internet and by public acknowledgement of the Israeli state, with the Israeli artists’ colony of Ein Hod.

Devleena Ghosh spoke of the sustained silencing of the stories of deep fear, violence and trauma which have remained unvoiced after Partition, allowing both the 'new' nations of India and Pakistan to construct 'national' narratives which demonized the 'other' by erasing the pain of the actual state formation. Her reflections on the subcontinent offered a parallel to Shalbak and Birch, but in this case it is not a settler colonial narrative of origin of the nation which erases experience of the past, but the divergent narratives of two 'post-colonial' new nations seeking to justify their bloody partition, itself an outcome of colonial rule. These three speakers traced the imperative of national histories to silence the internally defeated and to demonise the 'other' by silencing the contradictory evidence of the past, despite or perhaps because of it being often deeply traumatic and widely experienced. The 'dialectics of the unspeakable' generate a silence which meets the needs of the nation states, allowing them to defend their assertion of logical and defensible borders. Ilan Pappe considered the implications for the production of history in conditions of current bitter armed conflict where the demands from both colonizing Israeli and colonized Palestinian publics for a simple, empirical and 'factual' history are fuelled by the national aspirations of each side, silencing internally the voices of dissidents and the marginalized whether they are 
Israeli or Palestinian. Are there alternatives? Nimni explored the possibilities for a nonterritorial nationalism, in which the nation state itself would look and function in such a way as to undermine the need for competing claims to space and authority.

Another was the effect of colonialism on historical practice and the imagining of the nation. Ghosh reflected on the sustained legacy of colonialism on the subcontinent in the concept of borders and discussed the intense but unspoken tension arising from their simultaneous closure and porosity. Ryan explored the concept of genocide through the dynamics of silencing within the colonial Australian nation and considered the outcomes of comparative work on the emerging narratives of non-Indigenous and Indigenous historians. Curthoys too engaged with the question of the relevance of genocide in Australia, turning to a consideration of Lemkin's conceptualization of the concept and then considering its implications for colonialism and the resulting nation. Finally Hage explored the metaphor of the warrior mentality and its implications of a continuing settler colonialism in Australia and globally.

Yet each of the speakers was not only a scholar but an activist in the public sphere. Ultimately, it was the question of the public practice of history in the conditions of intense contestation which was most pressing. So the remaining two themes were focused on the practice of history in the public. One, considered most directly in Pappe's paper but reflected in many others and explored extensively in the discussions through the day, was the conceptual and strategic question of whether empiricism was an inevitable and necessary approach to public debate or if relativism, although harder to argue, was both possible and ultimately necessary. When public debate and tabloid media demand unequivocal 'truths' to prove an argument, how can principled historians broach the complex uncertainties of ambiguous evidence and unanswerable questions without seeming to prevaricate and compromise? And if the defenders of 'national' history insist on simplistic truths, their challengers are pushed into the opposing corner, seeking just as 'certain' a history to counter that of their opponents. The hard certainties of empiricism made for good headlines but poor negotiating positions and ever more polarized opponents.

So the final and perhaps most important theme was that explored by Ilan Pappe: how might people on opposite sides of the conflicts inquire together about the past? What 
might be the ways in which effective collaborations might fruitfully occur to create an understanding of the past which was not necessarily unitary or simple, but which instead drew on many perspectives to generate a new way to see the past and the present? How might change take place in the practice of history making?

Tony Birch had already pointed to 'phoney' collaborations and their frustrating outcomes. In the Palestinian/Israeli case of which Pappe writes, the pressure of competing nationalisms on each side of a conflict threatens to choke off the tentative steps towards collaborative research among dissidents and marginalized groups on all sides, like women and working people, whose aspirations are not well served by hollow narratives of origin myths and manufactured unities. Pappe offers thoughtful and balanced reflections, drawn from the Bridging Narratives group in Israel/Palestine, on how activist researchers might foster the possibilities for real collaborations in historical research which challenge the silences generated to the nationalism of both colonizers and colonized. His analysis arises from work in one of the most bitter and intractable conflicts the world is currently witnessing. The possibility of transformative collaboration in such a situation, however tentative and exploratory, holds out a glimpse of hope not only for the people of Palestine and Israel but for people in the similarly complex and entrenched conflicts and silences in India and Pakistan and in Australia.

\section{Reference}

Curthoys, A. \& Docker, J. (2005) Is History Fiction? UNSW Press and University of Michigan Press. 